\title{
About the Main Directions of Activity of Services and Divisions of the Penitentiary System and Internal Affairs Bodies in Countering Extremism and the Terrorist Threat at the Present Stage: Strategies and Methods of Prevention
}

\section{Sobre las principales direcciones de actuación de los servicios y divisiones del sistema penitenciario y los órganos internos en la lucha contra el extremismo y la amenaza terrorista en la etapa actual: estrategias y métodos de prevención}

\author{
Nikolay V. Rumyantsev" \\ Center of Studying of Problems of Management and the Organization Executions of \\ Punishments in Criminally-Executive System, Federal Penitentiary Service of Russia Research \\ Institute, Moscow, Russia. \\ ORCID: https://orcid.org/0000-0002-1170-8739 \\ Salikh Kh. Shamsunov \\ Center of Studying of Problems of Management and the Organization Executions of \\ Punishments in Criminally-Executive System, Federal Penitentiary Service of Russia Research \\ Institute, Moscow, Russia. \\ ORCID: https://orcid.org/0000-0001-8804-1920

\section{Maxim Yu. Taraso} \\ Center of Studying of Problems of Management and the Organization Executions of \\ Punishments in Criminally-Executive System, Federal Penitentiary Service of Russia Research \\ Institute, Moscow, Russia. \\ ORCID: https://orcid.org/0000-0001-5259-7003
}

Received 01-12-20 Revised 01-25-20 Accepted 04-13-20 On line 06-29-20

*Correspondence

Email: rumyantsevn.v@yandex.ru
Cite as:

Rumyantsev, N.V., Shamsunov, S. Kh., \& Taraso, M.Y. (2020). About the Main Directions of Activity of Services and Divisions of the Penitentiary System and Internal Affairs Bodies in Countering Extremism and the Terrorist Threat at the Present Stage: Strategies and Methods of Prevention. Propósitos y Representaciones, 8 (SPE2), e799. Doi: http://dx.doi.org/10.20511/pyr2020.v8nSPE2.799 


\section{Summary}

The relevance of the problem under study is due to the need to organize preventive work to counter extremist activities and terrorist threats in the country, implement measures to form the population's anti-terrorist consciousness, improve measures of an informational and propaganda nature and protect the information space of the State from the ideology of extremism and terrorism. The purpose is to find new solutions and to develop a structural and functional model aimed at preventing and countering the spread of religious extremist and terrorist activities on the territory of the State by the services and divisions of the Federal Penitentiary System of Russia (FPSR) and the Ministry of Internal Affairs of Russia (MIA of Russia) and other law enforcement agencies, state and public organizations, as well as a closer interaction of these organizations in the fight against destructive associations. The methodological basis of the research is made up of general scientific methods (dialectic and system-structural) and specific scientific methods of cognition (sociological and statistical). The theoretical basis is the work of domestic and foreign authors in the context of the problem being studied. The article presents the directions that can effectively solve the tasks set to law enforcement bodies and the penitentiary system, the goals of which are the prevention and counteraction of religious extremism and the terrorist threat, the need for additional work on training personnel, not only from among the employees of services and divisions of law enforcement agencies, but also state and public organizations, educational institutions responsible for organizing work in this direction, religious figures (clergy) who devoted themselves to church service. In addition, the problems of counteracting the activities of destructive religious organizations are reflected, which are: high level of confidentiality of the organizations; a thorough check by them of new members of the organization; fanaticism of members of a destructive religious organization and, as a result, the denial of any dissent; a high level of mutual distrust of the employees of the penal system, law enforcement agencies and persons serving sentences, as well as the lack of the necessary knowledge of religious norms about the difference between extremist ideologies and traditional religious teachings; insufficient information interaction between law enforcement agencies. It is aimed at the need to focus efforts to intensify the activities of the services and units of the penitentiary system, Internal Affairs bodies and other law enforcement agencies and public organizations on the prevention of extremist and terrorist activities, as well as the training of qualified personnel for work in this direction.

Keywords: structural and functional model, institutions of the penitentiary system, internal affairs bodies, the prevention of extremism and terrorism, destructive organizations.

\section{Resumen}

La relevancia del problema en estudio se debe a la necesidad de organizar un trabajo preventivo para contrarrestar las actividades extremistas y amenazas terroristas en el país, implementar medidas para formar la conciencia antiterrorista de la población, mejorar las medidas de carácter informativo y propagandístico y proteger el espacio informativo del Estado desde la ideología del extremismo y el terrorismo. El propósito es encontrar nuevas soluciones y desarrollar un modelo estructural y funcional destinado a prevenir y contrarrestar la propagación de actividades religiosas extremistas y terroristas en el territorio del Estado por parte de los servicios y divisiones del Sistema Penitenciario Federal de Rusia (FPSR) y el Ministerio del Interior de Rusia (MIA de Rusia) y otras agencias de aplicación de la ley, organizaciones estatales y públicas, así como una interacción más estrecha de estas organizaciones en la lucha contra las asociaciones destructivas. La base metodológica de la investigación está constituida por métodos científicos generales (dialécticos y sistémicos-estructurales) y métodos científicos específicos de cognición (sociológicos y estadísticos). La base teórica es el trabajo de autores nacionales y extranjeros en el contexto del problema que se estudia. El artículo presenta las orientaciones que pueden resolver eficazmente las tareas encomendadas a los cuerpos de seguridad y al sistema penitenciario, cuyos 
objetivos son la prevención y lucha contra el extremismo religioso y la amenaza terrorista, la necesidad de un trabajo adicional en la capacitación del personal, no solo de entre los empleados de los servicios y divisiones de las agencias policiales, pero también de las organizaciones estatales y públicas, las instituciones educativas responsables de organizar el trabajo en esta dirección, las figuras religiosas (clero) que se dedicaron al servicio de la iglesia. Además, se reflejan los problemas de contrarrestar las actividades de las organizaciones religiosas destructivas, que son: alto nivel de confidencialidad de las organizaciones; un control minucioso por parte de ellos de los nuevos miembros de la organización; fanatismo de miembros de una organización religiosa destructiva y, como resultado, la negación de cualquier disidencia; un alto nivel de desconfianza mutua hacia los empleados del sistema penal, los organismos encargados de hacer cumplir la ley y las personas que cumplen condenas, así como la falta del conocimiento necesario de las normas religiosas sobre la diferencia entre las ideologías extremistas y las enseñanzas religiosas tradicionales; interacción de información insuficiente entre los organismos encargados de hacer cumplir la ley. Se dirige a la necesidad de concentrar esfuerzos para intensificar las actividades de los servicios y unidades del sistema penitenciario, órganos de Asuntos Internos y otros organismos encargados de hacer cumplir la ley y organismos públicos en la prevención de actividades extremistas y terroristas, así como la formación de personal calificado personal para trabajar en esta dirección.

Palabras clave: modelo estructural y funcional, instituciones del sistema penitenciario, órganos de asuntos internos, prevención del extremismo y terrorismo, organizaciones destructivas.

\section{Introduction}

Having accumulated a huge system of versatile knowledge in its history, the world community, unfortunately, was unable to create a reliable barrier against terrorism and extremism phenomena that have turned into a serious problem for all mankind. Under contemporary conditions, they have surpassed the scope of the national problem not only of individual states, but have also gained international proportions (Kikot et al., 2004).

Crimes of an extremist nature and terrorism are characterized by increased social danger because they often entail irreparable harm to physical and mental health, killing a large number of people, leading to the destruction of material, spiritual and cultural values, etc. (Asmandiyarova, 2018).

Religious extremist and terrorist organizations are now increasingly using various forms of pressure on state authorities, as well as the elimination of political opponents, intimidation and other methods.

Radical organizations and various nationalist associations of an extremist orientation, often in order to achieve their illegal goals, "export" them to various countries, while possessing organized influential structures, extensive financial and economic opportunities and equipment. At the same time, the degree of danger of the spread of extremist and terrorist activities increases significantly in conditions of intensive migration, improvement of telecommunications, mass media and increasing social tension.

The growing professional qualifications of terrorists and extremists, their focus on causing maximum damage, the expansion of the arsenal of technical means used to commit terrorist acts, the high level of their financial support, and a number of other factors that confirm the conclusion about the increasing danger of modern extremism and terrorism and their transformation into a strategic threat on a global scale (Rybina \& Deren, 2019) are also of concern. 
It is no secret that extremist and terrorist activities currently pose a serious threat to any state and its society, undermining their foundations. These phenomena destroy established rules and norms of behavior, undermine security, and often manifest themselves in the commission of serious and particularly serious crimes (many major terrorist acts committed on the territory of a number of states are still remembered).

The extension of extremist and terrorist activities on the territory of states is undoubtedly facilitated by such factors as: the increasing flow of migration, which contributes to the penetration of foreign fighters into the territory of the states under the guise of refugees and labor migrants; the presence of ethnic organized criminal groups that assist criminal elements; the possibility of using telecommunications by persons prone to extremist and terrorist activities; the organization of recruitment of adherents through Internet resources; criminal financial transactions, etc.

According to international law enforcement agencies, including the Russian Federation, there is an ongoing desire of destructive forces to new manifestations of an extremist and terrorist nature. The ever-increasing number of people convicted of extremism and terrorism serving sentences in prison shows the seriousness of the situation and the need to take decisive steps to resolve this problem.

\section{Materials and Methods}

\section{Method of Research}

The following methods were used in the research: theoretical (analysis, synthesis, specification, generalization, method of analogies); diagnostic (questionnaire, testing, method of tasks and assignments); empirical (study of the experience of educational organizations, normative and educational documentation); experimental (stating, forming).

\section{Experimental Base of Research}

The experimental base of the research was the Research Institute of the Federal Penitentiary Service of Russia (the FPSR).

\section{Stages of the Study}

Scientists of the Research Institute of the FPSR have planned and implemented jointly with structural divisions and departmental educational organizations research projects that will undoubtedly help strengthen preventive work to counter extremist and terrorist activities. A similar work was organized in scientific and educational institutions of the Ministry of Internal Affairs of the Russian Federation, etc.

\section{Results}

Among the main tasks for the implementation of activities in this direction are such as: the implementation of measures to form the population's anti-terrorist consciousness, improving measures of an informational and propaganda nature and protecting the information space of the state from the ideology of terrorism; the development of organizational and other measures aimed at improving the performance of counter-terrorism entities. 
It is no secret that one of the important factors in the work to prevent and combat the extremist and terrorist threats is the vigorous activity of services and units of internal affairs bodies and bodies of the penitentiary system. For each of these departments, tasks related to improving the effectiveness of preventive work with people exposed to the ideology of terrorism, as well as those falling under its influence, are defined.

These tasks include: awareness-raising activities involving religious and public organizations, psychologists to explain the criminal nature and public danger of terrorism with persons serving sentences in penal institutions; implementation of preventive measures involving representatives of religious and public organizations, psychologists in the form of individual interviews with persons serving sentences not related to imprisonment, including for crimes of a terrorist nature; conducting interviews with family members of persons involved in terrorist activities to explain the Russian legislation for participating in and facilitating terrorist and extremist activities; conducting preventive conversations about non-acceptance of the ideology of terrorism with persons who are on the preventive register and are under public supervision in the police department in connection with involvement in the commission of offenses in the field of public security. In addition - it is necessary to organize the advanced training for employees involved in the implementation of counter-terrorism measures, etc.

As rightly noted at a conference at Moscow University of the MIA of Russia named after V.J. Kikot (2019), jointly organized by the MIA of Russia and Ministry of Foreign Affairs of Russia, during the discussion of the tasks in the fight against extremist and terrorist activities on the territory of Russia and strengthening of international cooperation in countering them: "... in modern conditions should not be geopolitical ambitions and contradictions and it is very important to consolidate the efforts of the international community in countering these negative challenges" in countering these negative challenges".

In the context of the destabilization of national security, a special concern is the problem of penetration in the penitentiary system and spread the ideology of extremism and terrorism, as suspects, accused and convicted of these types of destructive activities, often continue to carry out illegal activities in the prison and receive funding from the outside (Shamsunov \& Razumova, 2019).

Convicted of extremist and terrorist activities in places of detention, continue their illegal activities, attract new supporters. According to the leadership of the Anti-Terrorism Center of the CIS countries, this is one of the main problems, as the ideologists of radical extremism, pursuing their main goal - to recruit new supporters of the destructive movement among convicts, often end up in jail for intentionally committing minor ordinary crimes.

It should be noted that the work on countering extremist and terrorist activities, of course, has certain difficulties for the staff of the penal system and Internal Affairs bodies (hereinafter ATS). The conducted research has shown that among them: high level of confidentiality of the organizations; a thorough check by them of new members; their fanaticism and, as a result, the denial of any dissent; the lack of necessary knowledge of the staff about religious norms; a high level of distrust of staff of bodies by members of destructive religious organizations, etc.

Undoubtedly, each of the above-mentioned services will have to solve its own specific tasks related to countering the ideology of extremism and terrorism, as well as the resocialization of persons convicted of destructive religious activities.

The accumulated experience shows that not only in Russia, but also abroad, personnel who are able to effectively solve the goals and tasks set for law enforcement agencies, including the penitentiary system, aimed at preventing and countering religious extremism and terrorism, 
must be trained not only from among the employees of law enforcement services and divisions, but also from members of state and public organizations, educational institutions responsible for organizing work in this direction, as well as religious figures (clergy), dedicated to Church service. This was the path of the pastor, and later the head of the prison on the Norwegian island of Bastoi, Mr. Arne Kvernike Nielsen (Bagreeva, Shamsunov \& Bagreeva, 2019).

\section{Discussions and Conclusion}

Currently, the penitentiary system and Internal Affairs agencies of Russia are implementing measures aimed at fulfilling the tasks of countering religious extremism. A working group has been established to develop a set of measures to strengthen cooperation in this area between the FPSR, the MIA of Russia and other law enforcement agencies, as well as to prevent terrorism and extremist activities on the territory of penal institutions and beyond.

Also, in order to ensure proper interaction in strengthening counteraction to extremist and terrorist activities, law enforcement agencies hold collegiums, coordination and interdepartmental meetings of heads of law enforcement agencies and state authorities, interacting with religious anti-terrorist commissions (Belotserkovsky, 2010).

Scientists of the Research Institute of the FPSR are planning and implementing research projects together with structural divisions and educational organizations of the FPSR, which will undoubtedly help to strengthen preventive work to counter extremist and terrorist activities. Similar work is organized in scientific and educational institutions of the MIA of Russia.

The "deradicalization" programs implemented by some countries for many years have not yet produced definite and measurable results and leave open some important problems (Bertolasi 2018).

Scientists rightly note that the deideologization and deradicalization of associates of extremist and terrorist trends are not fully developed and require a broad scientific discussion on this issue.

Effective implementation, detection, suppression and disclosure of crimes committed by associates of extremist and terrorist activities are impossible without a thorough study of public relations and the definition of adequate mechanisms based on the laws of these phenomena.

\section{References}

Asmandiyarova, N.R. (2018). Victimological aspect in countering the ideology of extremism and terrorism. Materials of the International scientific and practical conference, pp. 122-132. Kazan: Izd-vo Akademii nauk RT.

Bagreeva, E.G, Shamsunov, S.Kh. \& Bagreeva, E.V. (2019). Ecoprison: Socio-Cultural Dreams or Legal Reality? Ekoloji, 28(107), 4985-4989

Belotserkovsky, S.D. (2010). Extremism: social, legal and criminological problems. Fight against modern organized forms of terrorism and extremism. Moscow: Ros. kriminolog. assots.

Bertolasi, E. (2018). Deradicalization of jihadists: a view from Italy. Materials of the International scientific and practical conference. URL: https://www.semanticscholar.org/paper/International-Scientific-and-PracticalConference-"-Bezdidko-Shumakova/ad5ab6d28c6829172a07c5edc6ec2016a12484b2 
Kikot, V.Ya. (2019). "I Serve The Law". In such conditions, there should be no place for geopolitical ambitions and contradictions. Newspaper of the Moscow University of the MIA of Russia, 3(68), 112-121.

Kikot, V.Ya., Kazantsev, S.Ya., Kofman, B.I. \& Eriashvili, N.D. (2004). Struggle of the problem of counteraction. Moscow: Unity Dana.

Rybina, S.N. \& Deren, I.I. (2019). Actual problems of normative and legal regulation of environmental terrorism. Fight against extremism in the penal system, 2(20), 117-120.

Shamsunov, H.S. \& Razumova, V.I. (2019). The Issues of interagency cooperation in the system of counteraction of legalization of incomes, received by criminal way and financing of terrorism. Bulletin of the Perm Institute of the Federal penitentiary service of Russia, 7(3), 531-536. 